\title{
IN VITRO CULTURES OF SALVIA OFFICINALIS L. AS A SOURCE OF ANTIOXIDANT COMPOUNDS
}

\author{
IZABELA GRZEGORCZYK ${ }^{1}$, IRENEUSZ BILICHOWSKI ${ }^{2}$, \\ ElŻBIETA MiKICIUK-OLASIK ${ }^{2}$, HALINA WYSOKIŃSKA ${ }^{1}$ \\ ${ }^{1}$ Department of Biology and Pharmaceutical Botany \\ ${ }^{2}$ Department of Pharmaceutical Chemistry and Drugs Analysis \\ Medical University of Łódź \\ Muszyńskiego 1, 90-151 Łódź, Poland \\ e-mail: botanika@pharm.am.lodz
}

(Received: June 9, 2004. Accepted: December 12, 2004)

\begin{abstract}
The concentrations of carnosic acid, carnosol and rosmarinic acid in different materials from differentiated (multiple shoot cultures and regenerated plants) and undifferentiated (callus and cell suspension) in vitro cultures of Salvia officinalis were determined by HPLC. The results suggested that diterpenoid (carnosic acid and carnosol) production is closely related to shoot differentiation. The highest diterpenoid yield $\left(11.4 \mathrm{mg} \mathrm{g}^{-1}\right.$ for carnosic acid and $1.1 \mathrm{mg} \mathrm{g}^{-1}$ for carnosol) was achieved in shoots of 10-week-old micropropagated plants. The levels were comparable to those found in shoots of naturally growing plants. Undifferentiated callus and cell suspension cultures produced only very low amounts of carnosol (ca. $0.05 \mathrm{mg} \mathrm{g}^{-1}$ of dry weight). In contrast, content of rosmarinic acid in callus and suspension cultures as well as shoots growing in vitro and in vivo was similar and ranged between 11.2 and $18.6 \mathrm{mg} \mathrm{g}^{-1}$ of dry weight.
\end{abstract}

KEY WORDS: carnosic acid, carnosol, rosmarinic acid, Salvia officinalis, in vitro cultures.

\section{INTRODUCTION}

Sage, Salvia officinalis L. (Lamiaceae) is an aromatic perennial plant native to southern Europe and Asia Minor. It is cultivated as a culinary herb and as a plant of great medicinal importance, officially listed in Pharmacopoeias of many countries throughout the world. Leaf extracts of this plant have antibacterial (Farag et al. 1989), antiviral (Tada et al. 1994), anti-inflammatory (Baricevic et al. 2001), antihydrotic (Leung 1989) and antioxidant properties (Cuvelier et al. 1994; Miura et al. 2002). It has been shown that antioxidant properties of sage extracts have been attributed to their major abietane-type diterpenoids: carnosic acid (CA) and carnosol (Car) as well as rosmarinic acid (RA) (caffeoyl derivative) (Cuvelier et al. 1994; Miura et al. 2002). Both carnosic acid and carnosol have been shown to be stronger antioxidants than synthetic antioxidants (butylated hydroxytoluene and butylated hydroxyanisole) in assays of their activity by the Rancimat method (Chen et al. 1992). These diterpenoids were also shown to inhibit superoxide anion production in the xanthone oxidase system (Haraguchi et al. 1995). According to Richheimer et al. (1999) their radical scavenging activity follows a mechanism analogous to that of other antioxi- dants, such as $\alpha$-tocopherol and is caused by the presence of two o-phenolic hydroxyl groups found at $\mathrm{C}_{11}$ and $\mathrm{C}_{12}$ of the molecules (Fig. 1). The diterpenoid compounds, besides the strong antioxidant activity, have also medicinal properties. For example, carnosic acid exerted a strong inhibitory effect on HIV-protease in cell-free assays (Paris et al. 1993) and skin tumorgenesis was inhibited by carnosol (Huang et al. 1994).

Rosmarinic acid (Fig. 1) also accounts for the antioxidant activity of sage. When measuring the radical scavenging effect on 1,1-diphenyl-2-picrylhydrazyl (DPPH) free radical, the antioxidative effect of rosmarinic acid $\left(\mathrm{EC}_{50}=2.7 \mu \mathrm{g} / \mathrm{ml}\right)$ was comparable to that of ascorbic acid (Lamaison et al. 1991).

Plant cell tissue culture has been considered as an alternative to produce secondary metabolites. However, only a few studies have reported on production of compounds with antioxidant activity in in vitro culture of Salvia officinalis. Hippolyte et al. (1992) reported the accumulation of RA in cell suspension culture of this species. Phenolic compounds with antioxidant activity have been found in shoot culture of S. officinalis by Santos-Gomes et al. (2002). The present report describes the establishment of callus and suspension cultures of S. officinalis and the pro- 
<smiles>CC(C)c1cc2c(c(O)c1O)[C@]1(C(=O)O)CCCC(C)(C)[C@@H]1CC2</smiles>

carnosic acid<smiles>CC(C)c1cc2c(c(O)c1O)OC1(C=O)CCCC(C)(C)C2CC1O</smiles>

carnosol<smiles>O=C(/C=C/c1ccc(O)c(O)c1)OC(Cc1ccc(O)c(O)c1)C(=O)O</smiles>

rosmarinic acid
Fig. 1. The structure of some antioxidant compounds in Salvia officinalis L. duction of antioxidant compounds i.e. carnosic acid, carnosol and rosmarinic acid in the cultures as well as in shoot cultures and shoots and roots of in vitro regenerated plants.

\section{MATERIAL AND METHODS}

\section{Plant material}

Seeds of Salvia officinalis provided by the Garden of Medicinal Plants of Łódź were chosen as the initial plant material. Seeds were washed in running tap water and were surface sterilized using sodium hypochlorite (1\%) for 15 min and then rinsed three times in sterile distilled water. Surface sterilized seeds were placed on MS (Murashige and Skoog 1962) agar (0.7\%, provided by Sigma-Aldrich) medium supplemented with sucrose $(3 \mathrm{~g} / \mathrm{l})$, kinetin 0.02 $\mathrm{mg} / \mathrm{l}(0.1 \mu \mathrm{M})$ and gibberellic acid $1 \mathrm{mg} / \mathrm{l}(2.9 \mu \mathrm{M})$ for germination. The 3-week-old seedlings provided material for in vitro cultures used in this study. For comparison, shoots and roots of 10-week-old original S. officinalis plants were used. The plants grown in the garden were initiated from the same seeds as in vitro cultures.

Induction of callus and cell suspension cultures

Salvia officinalis callus culture was obtained from hypocotyls (1 cm long) of 3-week-old aseptically growing seedlings. The explants were transferred into $25 \mathrm{ml}$ of MS agar $(0.7 \%)$ medium containing $3 \mathrm{~g} / \mathrm{l}$ sucrose, $0.1 \mathrm{mg} / 1(0.54 \mu \mathrm{M})$ NAA ( $\alpha$-naphthaleneacetic acid), 0.2 $\mathrm{mg} / \mathrm{l}(0.89 \mu \mathrm{M}) \mathrm{BA}$ (6-benzyladenine), $0.5 \mathrm{mg} / \mathrm{l}(2.26 \mu \mathrm{M})$ 2, 4-D (2,4-dichlorophenoxyacetic acid). After 4 weeks, the calluses derived on surface of the explants were transferred into fresh medium and subcultured at 3-week intervals. The suspension culture was initiated by transferring ca. $3 \mathrm{~g}$ callus from the $2 \mathrm{nd}$ passage into $50 \mathrm{ml}$ of liquid MS medium supplemented with $3 \mathrm{~g} / \mathrm{l}$ sucrose, $0.1 \mathrm{mg} / \mathrm{l} \mathrm{NAA}$,
$0.2 \mathrm{mg} / \mathrm{l} \mathrm{BA}, 0.5 \mathrm{mg} / \mathrm{l}$ 2, 4-D. The culture was maintained in $300 \mathrm{ml}$ Erlenmeyer flasks on a rotary shaker (100 rpm) at intervals of 14 days.

After 7 and 17 subcultures, callus and cells from the suspension culture were collected for phytochemical analysis.

\section{Establishment of shoot culture and plant regeneration}

The shoot culture was initiated from shoot tips of 3-week-old aseptically germinated seedlings of $S$. officinalis. They were grown on MS agar supplemented with 3\% sucrose, IAA (indole-3-acetic acid) $0.1 \mathrm{mg} / 1(0.57 \mu \mathrm{M}), \mathrm{BA}$ $0.45 \mathrm{mg} / \mathrm{l}(2.22 \mu \mathrm{M})$ and subcultured every 5 weeks. Investigations of secondary metabolites were done with shoots from the 6th and the 12th passages. When complete plantlets were needed these shoots were transferred into fresh half-strength MS (1/2 macronutrients) agar medium without growth regulators. After 4 weeks rooted plantlets were moved to small pots containing a sterilized mixture of sand, peat and soil $(3: 3: 4 \mathrm{v} / \mathrm{v} / \mathrm{v})$. They were grown in the greenhouse for 10 weeks.

\section{Culture conditions}

All cultures were kept in the growth chamber at $26 \pm 2{ }^{\circ} \mathrm{C}$ under continuous light provided by cool-white fluorescent lamps at a PPED of $40 \mu \mathrm{M} \mathrm{m}^{-2} \mathrm{~s}^{-1}$.

\section{Extraction and quantitative determination of $R A$}

Dried and powdered plant materials $(250 \mathrm{mg})$ were extracted twice with $30 \mathrm{ml}$ boiling methanol (for 2 hours) similar to Kochan et al. (1999). The combined extracts were filtered and evaporated to dryness. The residue was dissolved in $5 \mathrm{ml}$ of methanol and subjected to HPLC (high performance liquid chromatography). HPLC analysis was performed on a Waters (Milford, USA) Symetry ${ }^{\circledR}$ C18 column $(4.6 \times 150 \mathrm{~mm}, 3.5 \mu \mathrm{m})$ with $2 \mathrm{~cm}$ guard column using 
acetonitrile/0.1\% o-phosphoric acid 30:70 (v/v) at flow-rate of $1 \mathrm{ml} / \mathrm{min}$, and the column was maintained at ambient temperature. RA was detected at $\lambda=330 \mathrm{~nm}$. It was identified by comparison of its retention time $(\mathrm{Rt}=4 \mathrm{~min})$ and UV spectra in the 200-400 $\mathrm{nm}$ range with authentic sample run under identical conditions. Authentic RA was purchased from Carl Roth GmbH. RA content was determined with reference to a standard curve constructed with the known amounts of RA (over the range $0.1196 \mathrm{mg} / \mathrm{ml}$ $1.914 \mathrm{mg} / \mathrm{ml}$ ). The quantitative determination was made by measuring its peak area.

\section{Extraction and quantitative determination of carnosic acid and carnosol}

Dried and powdered plant materials (500 mg) were extracted with acetone. The details of extraction procedure were similar to described by Santos-Gomes et al. (2002). The residue obtained was dissolved in $5 \mathrm{ml}$ methanol and analyzed on HPLC system by an adaptation of the method described by Okamura et al. (1994), using a Waters Symetry ${ }^{\circledR} \mathrm{C} 18$ column $(4.6 \times 150 \mathrm{~mm}, 3.5 \mu \mathrm{m})$ with $2 \mathrm{~cm}$ guard column. The solvent system was acetonitrile $/ 0.1 \%$ o-phosphoric acid 65:35 (v/v). The analysis was carried out with a flow rate of $1 \mathrm{ml} / \mathrm{min}$, the column was maintained at ambient temperature and compounds were detected by absorption at $230 \mathrm{~nm}$. Identification was achieved by comparison of retention times and UV spectra (in range of 200-400 $\mathrm{nm}$ ) with commercial standards of carnosol (provided by Cayman Chemical Company) and carnosic acid (provided by Sigma-Aldrich). The retention times (min) for Car and CA were 6.1 and 10.7, respectively. The calibration curves, constructed separately for Car and CA, were linear above the range 42.4-636 $\mu \mathrm{g} / \mathrm{ml}$ and 34.4-516 $\mu \mathrm{g} / \mathrm{ml}$, respectively.

The Waters LC system consisted of a Waters 600 pump and a Waters 996 Photodiode detector, a Rheodyne injector fitted with a $5 \mu$ sample loop and Millennium 3.2 chromatography manager software and System Suitability were used. All solvents used for the preparations of the samples and mobile phases were HPLC grade. HPLC isocratic grade methanol, acetonitrile and phosphoric acid were supplied from J.T. Baker (Deventer, Holland).

All experimental analyses were carried out on a minimum of three independent samples for each plant material. The estimated values are the means of samples for these experiments \pm standard error of the mean. The amounts of the compounds were expressed in $\mathrm{mg} \mathrm{g}^{-1}$ of dry weight.

\section{RESULTS AND DISCUSSION}

\section{Establishment of suspension, callus and shoot cultures}

Callus cultures of S. officinalis were inducted from hypocotyl explants as described in section of Material and methods. Calluses were friable with a light green color. Their fresh weight increased 21 times within 3 weeks, as compared to the original weight $(280 \mathrm{mg})$. Cell suspension culture was initiated, when hypocotyl derived calluses were transferred into liquid medium. The medium used for cell suspension was generally the same as for callus but without agar. The suspension culture attained a maximum fresh weight $10.9 \mathrm{~g}$ per flask within 14 days, when inoculated approximately $0.9 \mathrm{~g}$ in fresh weight. In vitro shoot culture was obtained through proliferation of shoot tips excised from aseptically germinated seedlings with an average of 3 shoots per initial explant within 5 weeks. The shoots were rooted and plants appear to be growing normally in the greenhouse. Protocol for micropropagation of S. officinalis has been reported earlier (Grzegorczyk and Wysokińska 2004).

\section{Production of antioxidant compounds in in vitro cultures}

Using HPLC analysis, callus, cell and shoot cultures as well as shoots and roots of 10-week-old in vitro-propagated plants were investigated for CA, Car and RA contents. For comparison, the compound contents of shoots and roots of sage grown from seeds in the garden were also determined. The plants were the same age as in vitro regenerated plants (10-week-old). The results are presented in Table 1.

It was found that shoots of both micropropagated plants and naturally growing plants produced the highest diterpenoid levels, namely, $10-11.5 \mathrm{mg} \mathrm{g}^{-1}$ of carnosic acid and about $1.1 \mathrm{mg} \mathrm{g}^{-1}$ of carnosol, on a dry weight basis, whereas in the roots of the plants only small amounts of Car (max. $\left.0.09 \mathrm{mg} \mathrm{g}^{-1}\right)$ and CA $\left(0.07 \mathrm{mg} \mathrm{g}^{-1}\right)$ were found. The significantly higher amounts of carnosol and carnosic acid detected in the shoots compared to those in the roots suggest that the shoots are the site of the biosynthesis and probably accumulation of the compounds. It has earlier been reported that the biosynthesis of the diterpenoids is closely related to the formation of chloroplasts and that the root tissue does not participate in their biosynthesis, but can be served as a storage organ (Munne-Bosch and Alegre 2001; Del Bano et al. 2003). Therefore, it is interesting to examine the production of antioxidant diterpenoids in shoot culture of Salvia officinalis. We found that the culture produced 2.6-5 $\mathrm{mg} \mathrm{g}^{-1}$ of CA and $0.6 \mathrm{mg} \mathrm{g}^{-1}$ of carnosol. The values, especially in the case of carnosic acid were lower by several orders of magnitude than those in shoots of the whole plants (Table 1). The results presented in Table 1 indicate also that the sage shoot culture maintained the abili-

TABLE 1. Carnosic acid, carnosol and rosmarinic acid contents in callus, cell suspension cultures, cultured shoots, in vitro regenerated plants and the seed derived plants of Salvia officinalis $\mathrm{L}$.

\begin{tabular}{lccc}
\hline \multirow{2}{*}{ Analyzed plant materials } & \multicolumn{3}{c}{ Compound contents (mg/g dry weight) } \\
\cline { 2 - 4 } & CA & carnosol & RA \\
\hline $\begin{array}{l}\text { Shoot culture } \\
\text { passage 6 }\end{array}$ & $2.61 \pm 0.16$ & $0.58 \pm 0.019$ & $14.21 \pm 0.09$ \\
passage 12 & $4.77 \pm 0.15$ & $0.63 \pm 0.007$ & $16.30 \pm 0.14$ \\
& & & \\
Callus culture & & & \\
passage 7 & n.d. & $0.06 \pm 0.0015$ & $11.21 \pm 0.24$ \\
passage 17 & n.d. & $0.04 \pm 0.0004$ & $15.77 \pm 0.20$ \\
& & & \\
Cell suspension culture & & & \\
passage 7 & n.d. & $0.05 \pm 0.0006$ & $13.68 \pm 0.19$ \\
passage 17 & n.d. & $0.05 \pm 0.0003$ & $18.57 \pm 0.32$
\end{tabular}

In vitro regenerated

plants (10-week-old)

$\begin{array}{lccc}\text { shoots } & 11.37 \pm 0.16 & 1.09 \pm 0.008 & 12.23 \pm 0.17 \\ \text { roots } & 0.07 \pm 0.01 & 0.09 \pm 0.004 & 7.23 \pm 0.20\end{array}$

Plants from seeds

$\begin{array}{lccc}\text { shoots } & 10.1 \pm 0.15 & 1.14 \pm 0.040 & 18.46 \pm 0.22 \\ \text { roots } & \text { n.d. } & 0.07 \pm 0.002 & 8.18 \pm 0.36\end{array}$

n.d. - not detected 
ty to produce diterpenoids during at least one-year period and even the content of compounds slightly increased with the number of subculturing of the starting material. CA concentration, in the culture obtained by using shoot tips, excised from the 12th passage was about $5 \mathrm{mg} \mathrm{g}^{-1}$ of dry weight i.e. twice higher in comparison with that in the culture initiated from shoot tips from the 6th passage. Only one report on the occurrence of carnosol and carnosic acid in S. officinalis, shoot culture has been published, so far (Santos-Gomes et al. 2002). In contrast to our results, in the sage shoots culture analyzed by the authors, carnosol was a predominant compound; its level reached up to 1.8 $\mathrm{mg} \mathrm{g}^{-1}$ of dry weight, whereas the content of CA was only $0.2 \mathrm{mg} \mathrm{g}^{-1}$ of dry weight. The data clearly indicates that accumulation of carnosic acid in the culture established by Santos-Gomes et al. (2002) was much lower compared to that in multiple shoots used in the experiments described in this work. Several suggestions may be proposed to account for the reasons of these differences in product levels between these cultures. One may be the fact that different media were used in both experimental models. In comparison with our culture, shoots obtained by Santos-Gomes et al. (2002) were grown on MS media containing higher amount of cytokinin (1.5 mg/l BA or 1.5-4 mg/l kinetin). The biosynthesis of secondary metabolites is often affected by concentration of growth regulators (Su 1995; Swagata and Jha 2001). Another explanation may be connected with the instability of carnosic acid. According to many authors for example Schwarz et al. (1992), CA may give rise to carnosol during the extraction procedure (if the contact with air is not prevented) and within the plants after enzymatic dehydrogenation. The process is induced by environmental factors, such as temperature, light, effect of harvesting time and also kind of solvent used for extraction (Schwarz et al. 1992; Okamura et al. 1994; Cuvelier et al. 1996; Miura et al. 2002). Additionally, it is also possible that variability of diterpenoid production might be the consequence of fenotypic and/or genotypic differences between these cultures caused, for example, by the stage of growth of the starting material, thus supporting the necessity of selection of highyielding strains. According to Cuvelier (1996) the quality of sage and rosemary extracts and their antioxidative properties was dependent on the quality of the original plant, the harvesting date and its storage.

In the present study also unorganized callus and cell cultures of $S$. officinalis could synthesize carnosol, but only in very low contents $\left(0.04-0.06 \mathrm{mg} \mathrm{g}^{-1}\right.$ of dry weight). CA was undetectable in these materials. This finding raised the following question, whether carnosol is a true compound of unorganized cultures or a product of degradation of carnosic acid. Irrespective of the answer, our study provides the first evidence that carnosol is present in undifferentiated cultures. So far neither carnosol nor carnosic acid have been found in undifferentiated non-green rosemary callus culture by Caruso et al. (2000).

In this work, it was reported that in vitro cultures of $S$. officinalis produced also rosmarinic acid, the caffeic acid derivative. It was found that RA contents in callus and suspension cultures as well as in shoots growing in vitro and in vivo was similar and ranged between 11.2 and $18.6 \mathrm{mg}$ $\mathrm{g}^{-1}$ on the basis of dry weight. The amounts were twice as high as that in roots of both naturally growing and in vitro regenerated plants (Table 1). It was earlier demonstrated, that RA was produced in in vitro cultures of broad range of plant species including cultures of S. officinalis, in which RA concentration varied from $1.4 \%$ up to $36 \%$ of dry weight, after optimization of culture conditions (Whitaker et al. 1984; Hippolyte et al. 1992). On the other hand, Gomes et al. (2002) reported a maximum production of $2.8 \mathrm{mg} \mathrm{g}^{-1}$ RA of dry weight from the sage shoot culture i.e. 5-6 times less than that in the shoot culture described in the present study (Table 1). According to observations of many investigators and the results of our work it has been shown that accumulation of RA is not determined by a degree of culture differentiation. The ability to synthesize RA by in vitro cultures is rather dependent on plant species, cell line and its age (Whitaker et al. 1984; Hippolyte et al. 1992; Del Bano et al. 2003). This is the case with sage cell suspension obtained in this work, which after seven passages produced $13.7 \mathrm{mg} \mathrm{g}^{-1}$ of RA on the basis of dry weight. The amount increased to $19.0 \mathrm{mg} \mathrm{g}^{-1}$ when the cells from the 17 th passage were analyzed (Table 1$)$. On the other hand, the biosynthesis of diterpenoids (carnosic acid and carnosol) is probably associated with differentiation process and the shoot formation seems to be of a great importance in obtaining the significant increase in the amount of the antioxidant compounds. The presence of carnosol in unorganized callus and cell cultures shows, however, that morphological dedifferentiation caused only a quantitative decrease in the diterpenoid content and seemed not to suppress totally the activity of specific enzymes involved in the biosynthesis and storage of the compound. This opens the way for further investigation focused on optimization of medium composition and culture conditions as well as the induction of specific stress conditions in order to improve diterpenoid production not only in the shoot culture, but also in suspended sage cells. Moreover, the comparison between the diterpenoid level in micropropagated plants and plants derived from seeds revealed that the former may be also considered as an alternative source of compounds. Currently, a considerable interest has been directed towards the production of the diterpenoids in particular taking into account their strong antioxidant activities.

\section{ACKNOWLEDGEMENTS}

This work was supported by the State Committee for Scientific Research (grant No. KBN-092/P05/2003).

\section{LITERATURE CITED}

BARICEVIC D., SOSA S., DELLA LOGGIA R., TUBARO A., SIMONOVSKA B., KRASNA A., ZUPANCIC A. 2001. Topical anti-inflammatory activity of Salvia officinalis L. leaves: the relevance of ursolic acid. J. Ethnopharmacol. 75: 125-132.

CARUSO J.L., CALLAHAN J., DECHANT C., JAYASIMHULU K., WINGET G.D. 2000. Carnosic acid in green callus and regenerated shoots of Rosmarinus officinalis. Plant Cell Rep. 19: 500-503.

CHEN Q., SKI H., HO C. 1992. Effects of rosemary extracts and major constituents on lipid oxidation and soybean lipoxygenase activity. JAOCS. 69: 999-1002.

CUVELIER M.E., BERSET C., RICHARD H. 1994. Antioxidant constituents in sage (S. officinalis) J. Agric. Food Chem. 42: 665-669. 
CUVELIER M.E., BERSET C., RICHARD H. 1996. Antioxidative activity and phenolic composition of pilot-plants and commercial extracts of sage and rosemary. JAOCS 73: 645-652.

DEL BANO M.J., LORENTE J., CASTILLO J., BENARENTEGARCIA O., DEL RIO J.A., ORTUNO A., QUIRIN K.W., GERARD D. 2003. Phenolic diterpenes, flavones and rosmarinic acid distribution during the development of leaves, flowers, steams and roots of Rosmarinus officinalis antioxidant activity. J. Agric. Food Chem. 51: 4247-4253.

FARAG R.S., DAW Z.Y., HEWEDI F.M., EL-BAROTY G.S.A. 1989. Antimicrobial activity of some Egyptian spice oils. J. Food Protection 52: 665-667.

GRZEGORCZYK I., WYSOKIŃSKA H. 2004. Mikrorozmnażanie Salvia officinalis $L$. z wierzchołków pędów. Biotechnologia 65: 212-218.

HARAGUCHI H., SAITO T., OKAMURA N., YAGI A. 1995. Inhibition of Lipid Peroxidation and Superoxide Generation by Diterpenoids from Rosmarinus officinalis. Planta Med. 61: 333-336.

HIPPOLYTE I., MARIN B., BACCOU J.C., JONARD R. 1992. Growth and rosmarinic acid production in cell suspension cultures of Salvia officinalis L. Plant Cell Rep. 11: 109-112.

HUANG M.T., HO C.T., WENG Z.X., FERRERO T., LOU Y.R., STANBER K., MA W., GEORGIADIS C., LASHIN J.D., CONNEY A. 1994. Inhibition of skin tumorigenesis by rosemary and its constituents carnosol and ursolic acid. Cancer Res. 54: 701-708.

KOCHAN E., WYSOKIŃSKA H., CHMIEL A., GRABIAS B. 1999. Rosmarinic acid and other phenolic acids in hairy roots of Hyssopus officinalis. Z. Naturforsch. 54c: 11-16.

LAMAISON J.L., PETITJEAN-FREYTET C., CARNAT A. 1991. Lamiacées médicinales á propriétés antioxydantes, sources potentielles d' acide rosmarinique. Pharm. Acta Helv. 66: 185-188.

LEUNG A.Y. 1989. Cosmetics made from Chinese herb extracts. Drug and Cosmetic Industry. April: 35-40.

MIURA K., KIKUZAKI H., NAKATANI N. 2002. Antioxidant activity of chemical components from sage and thyme measured by the oil stability index method. J. Agric. Food Chem. 50: 1845-1851.
MUNNE-BOSCH S., ALEGRE L. 2001. Subcellular compartmentation of the diterpene carnosic acid and its derivatives in the leaves of rosemary. Plant Physiol. 125: 1094-1102.

MURASHIGE T., SKOOG F. 1962. A revised medium for rapid growth and bioassays with tobacco tissue cultures. Physiol. Plant. 15: 473-497.

OKAMURA N., FUJIMOTO Y., KUWABARA S., YAGI A. 1994. High-performance liquid chromatographic determination of carnosic acid and carnosol in Rosmarinus officinalis and Salvia officinalis. J. Chrom. A. 679: 381-386.

PARIS A., STRUKELJ B., RENKO M., TURK V. 1993. Inhibitory effect of carnosolic acid on HIV-1 protease in cell free assays. J. Nat. Prod. 56: 1426-1430.

RICHHEIMER S.L., BAILEY D.T., BERNART M.W., KENT M., VININSKI J.V., ANDERSON L.D. 1999. Antioxidant activity and oxidative degradation of phenolic compounds isolated from rosemary. Recent Res. Dev. Oil Chem. 3: 45-58.

SANTOS-GOMES P.C., SEABRA R.M., ANDRADE P.B., FERNANDES-FERREIRA M. 2002. Phenolic antioxidant compounds produced by in vitro shoots of sage (Salvia officinalis L.). Plant Sci. 62: 981-987.

SCHWARZ K., TERNES W., SCHMAUDERER E. 1992. Antioxidative constituents of Rosmarinus officinalis and Salvia officinalis III: Stability of phenolic diterpenes of rosmary extracts under thermal stress as required for technological processes. $\mathrm{Z}$. Lebensm. Unters. Forsch. 195: 104-107.

SU W.W. 1995. Bioprocessing technology for plant cell suspension. Appl. Biochem. Biotechnol. 50: 189-229.

SWAGATA R., JHA S. 2001. Production of withaferin A in shoot cultures of Withania somnifera. Planta Med. 67: 432-436.

TADA M., OKUNO K., CHIBA K., OHNISHI E., YOSHII T. 1994. Antiviral diterpenes from Salvia officinalis. Phytochemistry. 35: 539-541.

WHITAKER R.J., HASHIMOTO R.T., EVANS D. 1984. Production of the secondary metabolite, rosmarinic acid by plant cell suspension cultures. Annals New York Acad. Sci. 435: 364-365. 